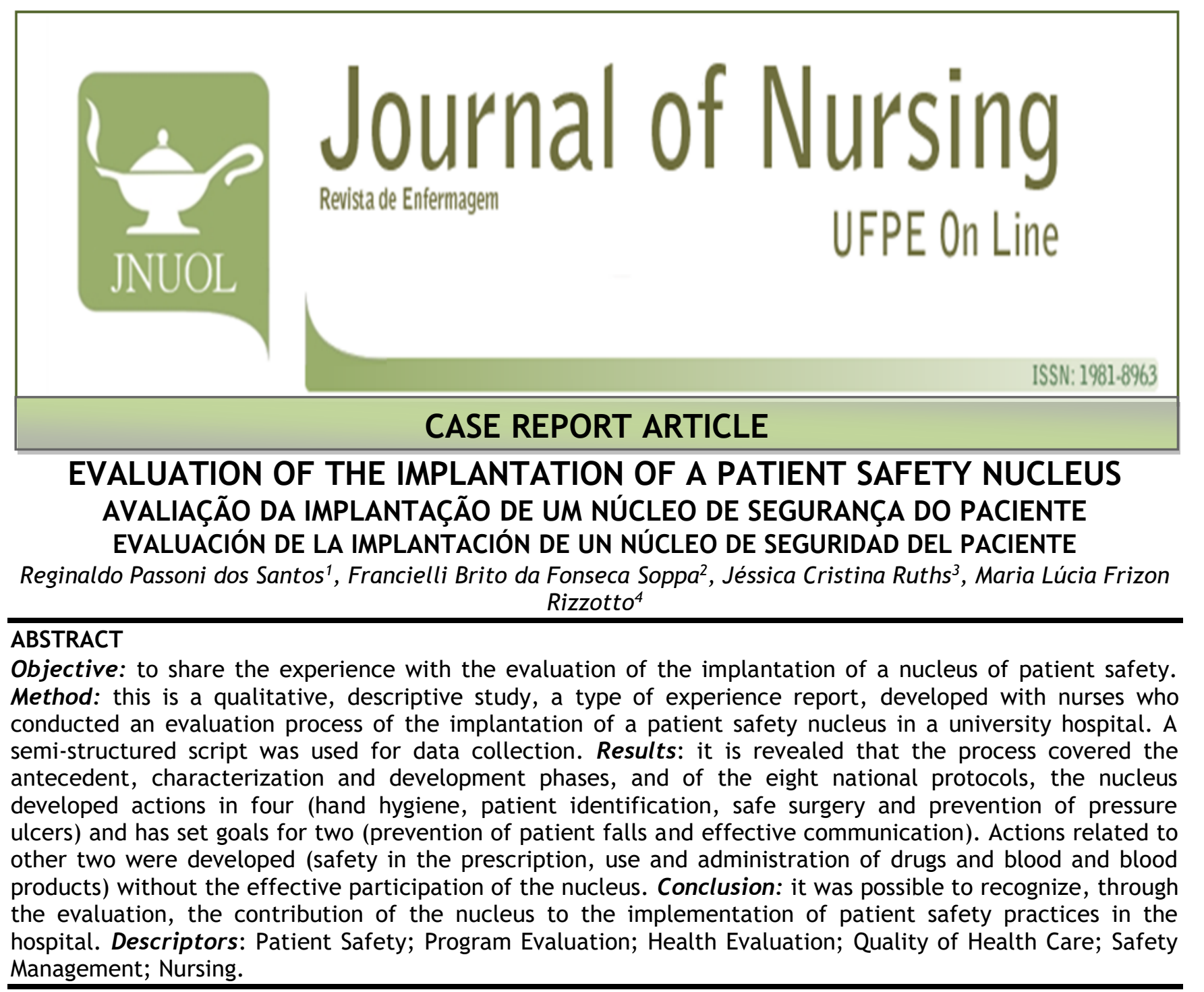

\title{
Management; Nursin
}

\section{RESUMO}

Objetivo: compartilhar a experiência com a avaliação da implantação de um núcleo de segurança do paciente. Método: trata-se de estudo qualitativo, descritivo, tipo relato de experiência, desenvolvido com os enfermeiros que conduziram um processo avaliativo da implantação de um núcleo de segurança do paciente em um hospital universitário. Utilizou-se, para a coleta de dados, um roteiro semiestruturado. Resultados: revela-se que o processo contemplou as fases de antecedentes, caracterização e desenvolvimento, e, dos oito protocolos nacionais, o núcleo desenvolveu ações em quatro (higienização das mãos, identificação do paciente, cirurgia segura e prevenção de úlceras por pressão) e traçou metas para dois (prevenção de quedas dos pacientes e comunicação efetiva). Desenvolveram-se ações ligadas a outros dois (segurança na prescrição, uso e administração de medicamentos e de sangue e hemoderivados) sem a participação efetiva do núcleo. Conclusão: permitiu-se reconhecer, pela avaliação, a contribuição do núcleo para a efetivação de práticas de segurança do paciente no hospital. Descritores: Segurança do Paciente; Avaliação de Programas e Projetos de Saúde; Avaliação em Saúde; Qualidade da Assistência à Saúde; Gerenciamento de Segurança; Enfermagem.

\section{RESUMEN}

Objetivo: compartir la experiencia con la evaluación de la implantación de un núcleo de seguridad del paciente. Método: se trata de un estudio cualitativo, descriptivo, tipo relato de experiencia, desarrollado con los enfermeros que condujeron un proceso de evaluación de la implantación de un núcleo de seguridad del paciente en un hospital universitario. Se utilizó, para la recolección de datos, un guion semiestructurado. Resultados: se revela que el proceso contempló las fases de antecedentes, caracterización y desarrollo, y de los ocho protocolos nacionales, el núcleo desarrolló acciones en cuatro (higienización de las manos, identificación del paciente, cirugía segura y prevención de úlceras por presión) y trazó metas para dos (prevención de caídas de los pacientes y comunicación efectiva). Se desarrollaron acciones relacionadas a otros dos (seguridad en la prescripción, uso y administración de medicamentos y de sangre y hemoderivados) sin la participación efectiva del núcleo. Conclusión: se permitió reconocer, por la evaluación, la contribución del núcleo para la efectuación de prácticas de seguridad del paciente en el hospital. Descriptores: Seguridad del Paciente; Evaluación de Programas y Proyectos de Salud; Evaluación en Salud; Calidad de la Atención de Salud; Administración de la Seguridad; Enfermería.

1,2,3 Masters, State University of the West of Paraná / UNIOESTE. Cascavel (PR), Brazil. Email: regi-pas@hotmail.com ORCID iD: https://orcid.org/0000-0002-7526-2510; Email: fran.b.f@hotmail.com ORCID iD: https://orcid.org/0000-0001-7382-3794; Email: ruths.jessica@gmail.com ORCID iD: https://orcid.org/0000-0002-7400-1191; ${ }^{4}$ PhD, State University of the West of Paraná / UNIOESTE. Cascavel (PR), Brazil. Email: frizon@terra.com.br ORCID iD: https://orcid.org/0000-0003-3152-1362 


\section{INTRODUCTION}

The main focus of the evaluation should be within health institutions to identify possible structural failures and/or processes that favor quality deviations, compromising the results of the assistance (direct or indirect) and, therefore, safety of the patient. ${ }^{1}$ The National Patient Safety Program (NPSP) ${ }^{2}$ was established with the aim of contributing to the qualification of care by the Ministry of Health, and among the regulations created, the Resolution of the Collegiate Board of Directors (CBD) no. 36, which describes the actions for the effectiveness of the NPSP, as well as making the implementation of the Patient Safety Nucleus (PSN) compulsory in health services. ${ }^{3}$

There is the PSN as the local body that should promote and support practical actions to develop the organizational culture of patient safety. Among its competencies are the implementation of the PNSP protocols, which address the following topics: 1) hand hygiene; 2) identification of the patient; 3) Safe Surgery; 4) pressure ulcer prevention; 5) prevention of falls in patients; 6 ) safety in the prescription, use and administration of medicines; 7) safety in the prescription, use and administration of blood and blood components; 8) effective communication. ${ }^{2}$

It is understood that, considering that the NPSP is a relatively recent program and that one of the forms of its practical implementation in health institutions should occur through the PSN, it is of the utmost importance that such an institution undergo periodic evaluations.

\section{OBJECTIVE}

- Share the experience by evaluating the deployment of a patient safety core.

\section{METHOD}

This is a qualitative, descriptive study, a type of experience report, developed with nurses who conducted an evaluation process of the implantation of a patient safety nucleus in a university hospital located in Paraná, Brazil, during the second semester of 2016. It used for the data collection, a semistructured script, which allowed to evaluate the implantation of the nucleus from the point of view of its effectiveness, identifying which of the national protocols of patient safety were already effective in the institution, after three years of core deployment. The results are presented descriptively, evidencing which and how the protocols were implemented.

The study was developed as an academic activity, developed during the Health Policy and Health-Disease Process classes of the Postgraduate Program in Biosciences and Health, State University of the West of Paraná (PPG-BCS/UNIOESTE). It was considered, therefore, given its nature, it is not necessary to present it to the Research Ethics Committee of the institution.

\section{RESULTS}

The processes of antecedents, characterization and development were considered by the process, which are detailed below.

It is reported that during the second semester of 2016 the subjects of "Health Policies and Health-Disease Process" were compulsory subjects of a Master's Program, which was the initial organization for the process. A challenge was launched at the beginning of the class, along with the general presentation on the subject and its objectives, by the teacher responsible for the same, that, from the theoretical knowledge transmitted in the subsequent meetings, the graduate students would have to develop, in practice, all the stages of the evaluative process of a health program.

The process was characterized as an evaluation of effectiveness, ie, it was sought to establish a relationship between the patient safety practices developed by the PSN and the eight protocols in the NPSP initially described. It is reported that the evaluation was of the ex-post type, carried out after the implementation of a service and/or program. It is considered that the evaluation process occurred in response to the challenge proposed in the discipline, whose purpose (function) of the evaluation was academic, of the strategic/relevance type.

It was developed by the authors, based on a specific theoretical framework, ${ }^{4}$ the evaluation process of PSN implementation through six phases. The following phases are presented in Figure 1, as well as the activities carried out in each one of them. 


\begin{tabular}{|c|c|}
\hline Phases & Performed activities \\
\hline $\begin{array}{l}1 . \quad \text { Engagement } \\
\text { interested persons }\end{array}$ & $\begin{array}{l}\text { Organization of the working group responsible for the evaluation process and } \\
\text { determination of the object of evaluation (program); } \\
\text { Nominal identification of those responsible for the program to be evaluated; } \\
\text { Orientations and guidance, by the teacher, for the next phases. }\end{array}$ \\
\hline $\begin{array}{l}2 . \\
\text { Presentation of the } \\
\text { evaluated program }\end{array}$ & $\begin{array}{l}\text { Comprehension about the program, through a theoretical study, with the } \\
\text { identification of their needs (scope / involvement), expectations (goals / } \\
\text { outcomes), activities (patient safety practices), resources (tools / protocols) } \\
\text { and other information, with the preparation of a report. }\end{array}$ \\
\hline $\begin{array}{l}\text { 3. Objective and } \\
\text { methodology }\end{array}$ & $\begin{array}{l}\text { Determination of the specific evaluation object (PSN implementation); } \\
\text { Strategic planning for conducting the evaluation process (methods, tools, } \\
\text { sources of information collection, resources needed and deadlines). }\end{array}$ \\
\hline $\begin{array}{l}\text { 4. Collection, meeting } \\
\text { and evaluation of } \\
\text { information }\end{array}$ & $\begin{array}{l}\text { Interview with a member of the PSN, with the application of a } \\
\text { semistructured questionnaire, composed of questions that would enable } \\
\text { information on patient safety practices, according to the eight NPSP } \\
\text { protocols; Systematization and analysis of data and information collected. }\end{array}$ \\
\hline 5. Evaluation report & $\begin{array}{l}\text { Theoretical-scientific support to the results of the critical analysis made to } \\
\text { the pooled evidence, based on the premises of the NPSP and its protocols. }\end{array}$ \\
\hline $\begin{array}{l}\text { 6. Sharing of lessons } \\
\text { learned }\end{array}$ & $\begin{array}{l}\text { Classroom discursive presentation of the stages of the evaluation process } \\
\text { and its results, with further discussion about their practical implications and } \\
\text { usefulness in order to promote improvements in the actions developed by } \\
\text { the PSN ;Sharing lessons learned with members of the hospital PSN; } \\
\text { Elaboration of a scientific article, in the experience reporting modality, to } \\
\text { share the lessons with the academic-scientific community. }\end{array}$ \\
\hline
\end{tabular}

Figure 1. Phases for the development of the evaluation process. Cascavel, PR, Brazil, 2016.

According to the information collected, the PSN was evaluated in 2013, in the form of a commission, and in the same year it was designated as the nucleus itself. At the end of 2014, the Patient Safety Plan 2015-2016 was prepared. The following table shows the patient safety practices developed in the institution after the PSN implementation, analyzed according to the eight NPSP protocols (Figure 2).

\begin{tabular}{|c|c|}
\hline Protocol & ${ }^{\dagger}$ Actions \\
\hline 1. Hand hygiene & $\begin{array}{l}\text { In partnership with several sectors of the institution (such as Hospital } \\
\text { Infection Control Service, Permanent Education Service, Building } \\
\text { Maintenance Service and Hospital Hygiene and Support Service, } \\
\text { among others): a) improvements in the physical structure of the } \\
\text { hospital, facilitating access solutions and repair of dispensers; b) } \\
\text { designation of a support service official to identify defective } \\
\text { dispensers, as well as maintenance and daily replacement of } \\
\text { solutions used for hand hygiene; c) implementation, analysis and } \\
\text { continuous monitoring of indicators of hand hygiene (quantitative } \\
\text { dispensing and use of alcoholic preparations); d) educational actions } \\
\text { with the institution's professionals; e) distribution and installation of } \\
\text { information material for the professional awareness of patients, } \\
\text { caregivers and family members. }\end{array}$ \\
\hline $\begin{array}{l}2 . \\
\text { Patient identification }\end{array}$ & $\begin{array}{l}\text { In partnership with the Hospital Internment Service and Permanent } \\
\text { Education Service: a) Initialization of the use of wristbands to } \\
\text { identify the patient, adhesive seal, inviolable and with printed data } \\
\text { obtained in the institution's electronic medical record system; b) } \\
\text { trainings with the teams on the national protocol and the } \\
\text { institutional project to identify the patient through the bracelets; c) } \\
\text { identification of the rate of use of the bracelets by the patient (use } \\
\text { rate in } 2014 \text { - general, } 45.5 \% \text { / in accordance with the national } \\
\text { protocol of approximately } 31 \% \text {, use rate in the first half of } 2016-80 \% \\
\text { in accordance with the national protocol); e) team meetings to know } \\
\text { the potentialities/fragilities of the institutional patient identification } \\
\text { project. }\end{array}$ \\
\hline 3. Safe Surgery & $\begin{array}{l}\text { Actions initiated in } 2014 \text { and led by a group of nursing professionals } \\
\text { from the surgical ward, with the support and assistance of the PSN: } \\
\text { a) revision and adaptation to the institutional reality of the NPSP safe } \\
\text { surgery check protocol; b) insertion of illustrative tables containing } \\
\text { the checklist in all operating rooms; c) permanent education about } \\
\text { the checklist and qualification of the team for its application; d) } \\
\text { meetings and discussions with obstetric center staff; e) in July 2016, }\end{array}$ \\
\hline
\end{tabular}




\begin{tabular}{|c|c|}
\hline & $\begin{array}{l}\text { official implantation of the protocol of safe surgery, in the } \\
\text { institutional scope, with forecast for reassessment in November } 2016 .\end{array}$ \\
\hline 4. Prevention of pressure ulcer & $\begin{array}{l}\text { In partnership with the team of the Commission on Dressings: a) in } \\
\text { July 2016, studies began for the elaboration of the institutional } \\
\text { protocol for the prevention of pressure ulcers (PPU), with the } \\
\text { implantation of the same, in the first instance, in the Unit intensive } \\
\text { care unit (ICU) for adults, due to the high incidence and prevalence } \\
\text { of PPU. }\end{array}$ \\
\hline 5. Prevention of patient falls & $\begin{array}{l}\text { No practical activity, effective or in progress, with the participation } \\
\text { of the PSN at the moment of the evaluation, but with actions in the } \\
\text { planning phase. }\end{array}$ \\
\hline $\begin{array}{l}\text { 6. Safety in the prescription, use } \\
\text { and administration of medicines }\end{array}$ & $\begin{array}{l}\text { According to information collected, at the time of the evaluation, } \\
\text { some actions were being carried out by the pharmacovigilance team, } \\
\text { however, without effective participation of the PSN. }\end{array}$ \\
\hline $\begin{array}{l}\text { 7. Safety in the prescription, use } \\
\text { and administration of blood and } \\
\text { blood products }\end{array}$ & $\begin{array}{l}\text { According to information collected, at the time of the evaluation, } \\
\text { some actions were being performed by the haemovigilance team, } \\
\text { however, without effective participation of the PSN. }\end{array}$ \\
\hline 8. Effective Communication & $\begin{array}{l}\text { No practical activity, effective or in progress, however, with actions } \\
\text { in the planning phase. }\end{array}$ \\
\hline
\end{tabular}

Figure 2. Practical patient safety actions developed by the PSN assessed. Cascavel, PR, Brazil, 2016.

$\dagger$ Instituted from the implementation of the PSN and, carried out or in progress at the time of the evaluation.

\section{DISCUSSION}

It was verified, with the evaluative process, that, after three years of its implantation, the PSN of the hospital had already collaborated effectively to develop actions related to four (50\%) of the eight national protocols, being still in strategic planning of the activities that would be developed for the implementation of two other protocols, as presented in table 2 .

It should be noted that the protocols are part of the NPSP, whose implementation in Brazil followed a worldwide trend of promoting patient safety and, at the national level, there was an improvement in the quality of the Health Care Network and, therefore, improvement of the Unified Health System, especially the use of proposed flows, procedures and indicators for each process. ${ }^{5}$

It is revealed that the implementation of the PSN, with the consequent elaboration of a PSP in the scope of the health services, is something to be celebrated, since it denotes a relevant advance for the incentive of the culture of patient safety and the quality of care to the health, explaining the concern of the local managers in supporting actions of improvements in the structure and in the processes, with final focus in the improvement of the results of the assistance provided by the institution.

It is understood, however, that establishing and periodically applying evaluative processes strongly corroborates the effectiveness analysis of the actions. ${ }^{6}$ In turn, the analysis of effectiveness is based on the re-discussion of work methodologies, the renewal of priorities and, therefore, is based on the reorganization of the strategic situation planning. ${ }^{1}$

The report "Self-Assessment of Patient Safety Practices - 2017" 7 was recently published by the National Agency of Sanitary Surveillance (ANVISA) ${ }^{7}$, which presents the results of self-assessment carried out by 984 hospitals throughout Brazil. It is observed that the most frequently implanted protocol refers to hand hygiene $(94.7 \%)$, followed by patient identification protocols (87.2\%).

From the evaluative process performed, it was found that PSN also emphasized the actions associated with these protocols, as well as the activities for the implantation of the protocol of safe surgery. On the other hand, the PSN had not developed effective practical actions for the implementation of protocols for fall prevention and effective communication (Table 2).

It was identified, in 2014, through research on errors and adverse events - performed in the same hospital - a culture unfavorable to effective communication among professionals. ${ }^{8}$ A number of associated factors are represented by the lack of effective communication, representing one of the main obstacles to the identification of incidents and adverse events. It is necessary, therefore, to implement alternative strategies for the knowledge of such occurrences. ${ }^{9}$

It is emphasized, therefore, that the evaluation process was conducted by postgraduate students, as a practical exercise carried out during the participation in 
compulsory discipline of an interdisciplinary masters program. It is important to highlight the discussion of patient safety issues in the academic context, by scholars, who "often during their training, professionals are not presented to the topic of patient safety, generating crisis situations, both in universities and in health care settings". 10:22

It was verified, in an investigation carried out by researchers of the Paulista School of Nursing, on the inclusion of the subject in the graduations in health, that patient safety is approached in a fragmented and superficial way in the courses, portraying the need to broaden the discussions in the university context. ${ }^{11}$ The experience was then shared by post-graduate students who also had little contact with the subject during graduation, being that students graduated in Nursing had better mastery of knowledge than colleagues with training in other subareas of health. It is recalled by scholars from the Federal University of Rio Grande do Sul that, in Brazil, Nursing has been standing out in relation to the debate on the subject. ${ }^{12}$

It is recorded, in this direction, that the university should be a space destined to teaching-learning, with diffusion of knowledge, acquisition of skills and, therefore, training of health professionals with capacity to act based on effective and safe care, as well as as well as knowing about aspects related to the evaluation of the effectiveness of the actions developed within the scope of care practice.

\section{CONCLUSION}

It was concluded that the evaluation process made it possible to recognize the contribution of the PSN to the institution of patient safety practices in the hospital environment, as well as to identify the points that deserve greater commitment on the part of the professionals that make up the nucleus, so that the actions necessary for the implementation of all national protocols. It was also contributed by the practical exercise of analyzing the component of a national health program, in an unique way, for the interdisciplinary training of students as postgraduate students, providing them with the necessary knowledge for professional performance with a broader vision, especially , for the comprehensive analysis of Brazilian public policies.

\section{REFERENCES}

\section{REFERÊNCIAS}

1. Furtado JP, Vieira-da-Silva LM. The evaluation of health programs and services in Brazil as a space for knowledge and practice. Cad Saúde Pública. 2014 Dec;30(12);2643- 55. Doi: $\underline{\text { 10.1590/0102-311X00187113 }}$

2. Ministério da Saúde (BR), Gabinete do Ministro. Portaria $n^{\circ} 529$, de $1^{\circ}$ de abril de 2013. Institui o Programa Nacional de Segurança do Paciente (PNSP) [Internet]. Brasília: Ministério da Saúde, 2014 [cited 2018 June 15]. Available from: http://bvsms.saude.gov.br/bvs/saudelegis/g m/2013/prt0529_01_04_2013.html

3. Ministério da Saúde (BR), Gabinete do Ministro. Resolução da Diretoria Colegiada (RDC) $n^{\circ} 36$, de 25 de julho de 2013. Institui ações para a paciente em serviços de saúde e dá outras providências [Internet]. Brasília: Ministério da Saúde; 2013 [cited 2019 July 12]. Available from: http://bvsms.saude.gov.br/bvs/saudelegis/an visa/2013/rdc0036_25_07_2013.html

4. The Center for the Advancement of Community Based Public Health, Baker QE, Davis DA, Gallerani R, Sánchez V, Viadro C. Uma estrutura de avaliação para os programas de saúde da comunidade [Internet]. Durham: CBPH; 2000 [cited 2018 July 15]. Available from:

http://www.imip.org.br/site/ARQUIVOS_ANEX O/Avalia\%C3\%A7\%C3\%A30\%20de\%20programas\% 20de\%20saude\%20em\%20comunidades;0510211 1;20100107.pdf

5. Capucho HC, Cassiani SHB. The need to establish a national patient safety program in Brazil. Rev Saúde Pública. 2013 Aug;47(4):1-8. Doi: $\quad$ http://dx.doi.org/10.1590/S00348910.2013047004402

6. Olds DM, Aiken LH, Cimiotti JP, Lake ET. Association of nurse work environment and safety climate on patient mortality: a crosssection study. Int. J. Nurs. Stud. 2017 Sep;74:155-161.

Doi:

\subsection{6/j.ijnurstu.2017.06.004}

7. Ministério da Saúde (BR), Agência Nacional de Vigilância Sanitária. Relatório de Autoavaliação Nacional das Práticas de Segurança do Paciente em Serviços de Saúde 2017 [Internet]. Brasília: Ministério da Saúde; 2018 [cited 2018 June 15]. Available from: http://portal.anvisa.gov.br/documents/33852 /459495/Relat\%C3\%B3rio+com+os+resultados+ da+Autoavalia\%C3\%A7\%C3\%A3o+2017/8c243765 -5190-46d2-a9ee-52f53cda2294

8. Souza VS, Kawamoto AM, Oliveira JLC, Tonini NS, Fernandes LM, Nicola AL. Errors and adverse events: the interface with health professionals' safety culture. Cogitare enferm. 
2015 July/Sept;20(3): 475-82. Doi: http://dx.doi.org/10.5380/ce.v20i3.40687

9. Santos RP, Luz MAP, Borges F, Carvalho ARS. Active search contributes to the identification of adverse events and incidentes in intensive care unit. Enferm Glob. [Internet]. 2017 [cited 2018 May 30];16(48):476-87. Available from: http://scielo.isciii.es/pdf/eg/v16n48/en_169 5-6141-eg-16-48-00465.pdf

10. Yoshikawa JM, Sousa BEC, Peterlini MAS, Kusahara DM, Pedreira MLG, Avelar AFM. Comprehension of undergraduate students in nursing and medicine on patient safety. Acta Paul Enferm. 2013; 26(1): 21-9. Doi: http://dx.doi.org/10.1590/S0103-

\section{$\underline{21002013000100005}$}

11. Bohomol E, Freitas MAO, Cunha ICKO. Patient safety teaching in undergraduate health programs: reflections on knowledge and practice. Interface comun saúde educ. 2016 July/Sept; 20(58):727-41. Doi: http://dx.doi.org/10.1590/1807-

\section{$\underline{57622015.0699}$}

12. Wegner W, Silva SC, Kantorski KJC, Predebon CM, Sanches MO, Pedro ENR. Education for culture of patient safety: implications to professional training. Esc Anna Nery Rev Enferm. 2016 June; 20(3): e20160068.

Doi:

http://dx.doi.org/10.5935/1414-

$\underline{8145.20160068}$

Submission: 2018/09/12

Accepted: 2018/01/10

Publishing: 2019/02/01

\section{Corresponding Address}

Reginaldo Passoni dos Santos

Rua Clodoaldo Ursulano, 426

Bairro Santa Felicidade

CEP: 85803-450 - Cascavel (PR), Brazil 